\title{
Severe Fever with Thrombocytopenia Syndrome Virus in Ticks in the Republic of Korea
}

\author{
Jun-Gu Kang ${ }^{1} \mathbb{0}$, Yoon-Kyoung Cho², Young-Sun Jo², Sun-Woo Han², Jeong-Byoung Chae'2, Jung-Eun Park², \\ Hyesung Jeong ${ }^{3}$, Weon-Hwa Jheong ${ }^{3}$, Joon-Seok Chae ${ }^{2, *}$ (1) \\ ${ }^{1}$ Korea Zoonosis Research Institute, Jeonbuk National University, Iksan 54531, Korea; ${ }^{2}$ Laboratory of Veterinary Internal Medicine, BK21 FOUR \\ Future Veterinary Medicine Leading Education and Research Center, Research Institute for Veterinary Science and College of Veterinary Medicine, \\ Seoul National University, Seoul 08826, Korea; ${ }^{3}$ National Institute of Wildlife Disease Control and Prevention, Gwangju 62407, Korea
}

\begin{abstract}
Severe fever with thrombocytopenia syndrome virus (SFTSV) is a zoonotic, tick-borne RNA virus of the genus Bandavirus (Family Phenuiviridae), mainly reported in China, Japan, and the Republic of Korea (Korea). For the purpose of this study, a total of 3,898 adult and nymphal ticks of species Haemaphysalis longicornis (94.2\%), Haemaphysalis flava (5.0\%), Ixodes nipponensis (0.8\%), and 1 specimen of Ixodes ovatus, were collected from the Deogyusan National Park, Korea, between April 2016 and June 2018. A single-step reverse transcriptase-nested PCR was performed, targeting the S segment of the SFTSV RNA. Total infection rate (IR) of SFTSV in individual ticks was found to be $6.0 \%$. Based on developmental stages, IR was $5.3 \%$ in adults and $6.0 \%$ in nymphs. The S segment sequences obtained from PCR were divided into 17 haplotypes. All haplotypes were phylogenetically clustered into clades B-2 and B-3, with $92.7 \%$ sequences in B-2 and 7.3\% in B-3. These observations indicate that the Korean SFTSV strains were closer to the Japanese than the Chinese strains. Further epidemiological studies are necessary to better understand the characteristics of the Korean SFTSV and its transmission cycle in the ecosystem.
\end{abstract}

Key words: Haemaphysalis longicornis, severe fever with thrombocytopenia syndrome virus, tick, National Park, vegetation, Korea

Severe fever with thrombocytopenia syndrome (SFTS) is caused by Dabie bandavirus (formerly, SFTS virus, SFTSV), a tick-borne zoonotic virus belonging to the genus Bandavirus (Family Phenuiviride) [1]. SFTSV has mainly been reported in China, Japan, and the Republic of Korea (Korea) [2-4]. The main clinical symptoms of SFTS include high fever, thrombocytopenia, leukopenia, and increased liver enzymes [2]. In animals, several cases of SFTS-like illnesses have been reported in companion animals like dogs and cats, and in cheetahs [5-8]. Recently, a confirmed case of SFTS in human was reported in 2020 from Taiwan [9]. Moreover, molecular and serological detections of SFTSV in both humans and animals have been reported from Vietnam, Taiwan, Thailand, Pakistan, and Myanmar [10-14]. These reports indicate that SFTSV could be circulating in other southern Asian countries as well as in the endemic countries such as China, Japan, and Korea.

\footnotetext{
- Received 2 November 2021, revised 12 December 2021, accepted 19 January 2022. *Corresponding author (jschae@snu.ac.kr)

(c) 2022, Korean Society for Parasitology and Tropical Medicine

This is an Open Access article distributed under the terms of the Creative Commons Attribution Non-Commercial License (https://creativecommons.org/licenses/by-nc/4.0) which permits unrestricted non-commercial use, distribution, and reproduction in any medium, provided the original work is properly cited.
}

The origin of SFTSV and its transmission cycle have not yet been completely elucidated. Although incidences of humanto-human or animal-to-human transmission have occasionally been reported, tick bites are the main transmission route of SFTSV. Several studies suggest that the main vector of SFTSV could be Haemaphysalis longicornis, the most dominant hardtick species in Korea [15-18]. SFTSV exhibits transstadial (from larva to nymph and/or adult) and transovarial transmission in H. longicornis [19]. In a previous study, we had reported the prevalence of SFTSV in ticks collected from 5 national parks in Korea [16]. However, that study was conducted for a short period, spanning from July to November 2015. Thus, an extended 3-year surveillance of hard ticks was undertaken in the Deogyusan National Park, Korea to monitor the SFTSV presence in the nature.

The ticks in Deogyusan National Park were observed to appear in March and disappear by November throughout the study period. Specimens were collected using flags $(0.5 \times 1.5$ sq. meters, white cotton) over a duration of 3 years (April 2016 to June 2018) (Fig. 1A). Through microscopic examinations, the collected specimens were classified into various species and developmental stages [20]. A total of 3,898 ticks were col- 


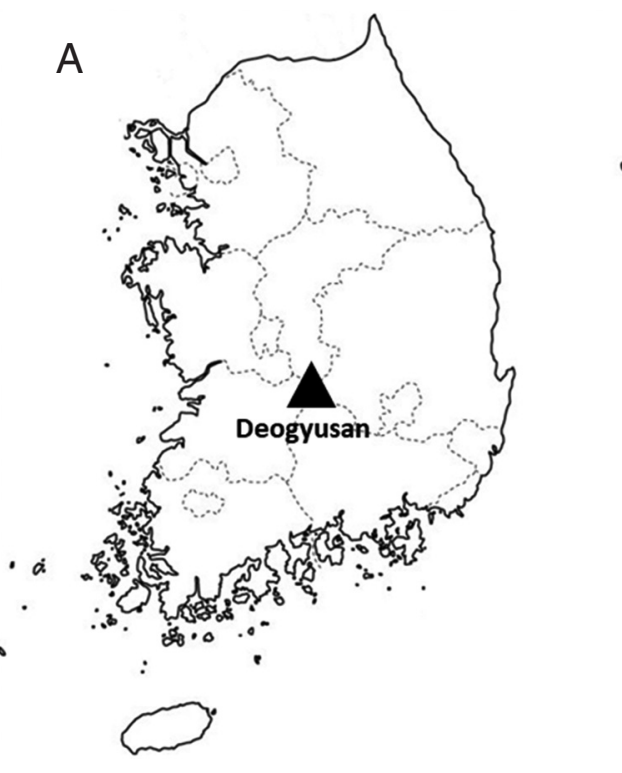

B

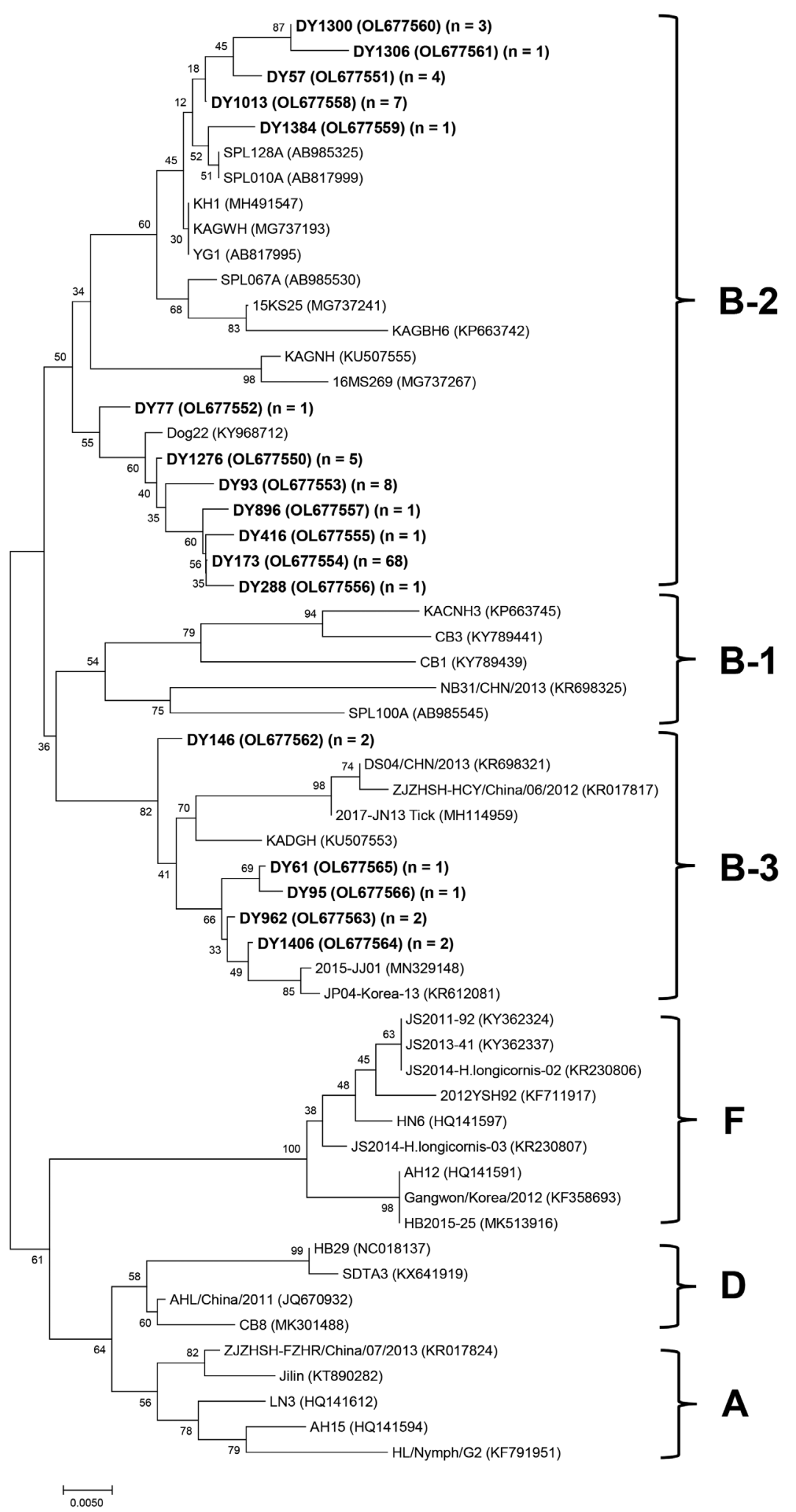

Fig. 1. (A) Map of the tick collection site, Deogyusan National Park, Korea. (B) Phylogenetic tree for SFTSV based on S segment sequences. Bold letters indicate the SFTSV sequences obtained from the ticks in this study. $n=$ number of sequences. A scale bar shows nucleotide substitutions per position. 
Table 1. Prevalence of severe fever with thrombocytopenia syndrome virus (SFTSV) in different developmental stages of ticks collected from Deogyusan National Park, Korea

\begin{tabular}{lcccc}
\hline Tick species & Developmental stage & No. of tested ticks & No. of SFTSV-positive ticks & Infection rate (\%) \\
\hline Haemaphysalis longicornis & Male & 54 & 1 & 1.9 \\
& Female & 173 & 11 & 6.4 \\
& Nymph & 3,444 & 206 & 6.0 \\
Haemaphysalis flava & Subtotal & 3,671 & 218 & 5.9 \\
& Male & 23 & 2 & 8.7 \\
& Female & 12 & 1 & 8.3 \\
Ixodes nipponensis & Symph & 159 & 12 & 7.6 \\
& Mabtotal & 194 & 15 & 0 \\
& Female & 16 & 0 & 0.0 \\
Ixodes ovatus & Nymph & 5 & 0 & 0.0 \\
Total & Subtotal & 11 & 0 & 0.0 \\
\hline
\end{tabular}

lected and classified into 4 species: $H$. longicornis (94.2\%), $H$. flava (5.0\%), Ixodes nipponensis (0.8\%), and I. ovatus (negligible). Detailed sample descriptions are mentioned in Table 1. A lot of larvae were collected from September to October through the years, but were not included in this study (data not shown). The seasonal larval distribution was very similar to that reported by a previous study [18]. The larvae were not classified into species because of their miniscule sizes and morphological similarities at the genus level. Noticeably, the adult and nymphal tick populations surged in April and sustained on high until June or July (Table 2). Although not included in Table 1, larvae were found in July, August, and September of 2017, numbering 63 in July, 50 in August, and 413 in September; they were grouped into 53 pools.

Adult and nymphal ticks were placed singly in $2 \mathrm{ml}$ round tubes and stored at $-80^{\circ} \mathrm{C}$ until further analysis. Larval ticks were pooled (10 larvae/pool), mixed with sterile stainless steel beads in $250 \mu \mathrm{l}$ tissue lysis buffer (iNtRON, Seongnam, Korea), and homogenized using TissueLyser II (Qiagen, Hilden, Germany) for $5 \mathrm{~min}$ at $30 \mathrm{~Hz}$. The homogenized samples were centrifuged at 13,000 rpm for $10 \mathrm{~min}$ at room temperature and the supernatant was collected. Viral RNA was extracted from the supernatant using Viral DNA/RNA Extraction kit (iNtRON) according to the recommended protocol and stored at $-80^{\circ} \mathrm{C}$ until use. To amplify the $\mathrm{S}$ segment of SFTSV RNA, 1-step reverse transcriptase (RT)-nested PCR was conducted using SFTSV-specific primer sets and One-step RT-PCR premix kit (SolGent, Daejeon, Korea), as previously described [16]. The first PCR primers were NP-2F (5'-CAT CAT TGT CTT TGC
CCT GA-3') and NP-2R (5'-AGA AGA CAG AGT TCA CAG CA3'). The nested PCR primers were N2-F (5'-AAY AAG ATC GTC AAG GCA TCA-3') and N2-R (5'-TAG TCT TGG TGA AGG CAT CTT-3'). RT reactions were performed with an initial step of 30 min at $45^{\circ} \mathrm{C}$ and 5 min at $94^{\circ} \mathrm{C}$ for denaturation. The PCR was run for 40 (first PCR) and 25 cycles (nested PCR) under the following conditions: $94^{\circ} \mathrm{C}$ for $20 \mathrm{sec}, 52^{\circ} \mathrm{C}$ for $40 \mathrm{sec}, 72^{\circ} \mathrm{C}$ for $30 \mathrm{sec}$, with a final extension step at $72^{\circ} \mathrm{C}$ for $5 \mathrm{~min}$. For nested PCR, $1 \mu \mathrm{l}$ of the first PCR products were used as template with HiPi PCR premix (Elpisbio, Daejeon, Korea). The amplicons were loaded on $1.2 \%$ agarose gel and observed under gel documentation system. The positive bands were purified using QIAquick Gel Extraction Kits (Qiagen). KH1 strain was used as a positive control [21]. The purified DNAs were sequenced using an automatic sequencer (3730 capillary DNA Analyzer; Applied Bio-systems, Foster City, California, USA). The sequences obtained were aligned by Clustal X (Ver 2.1) and analyzed using MEGA 7 [22,23]. A phylogenetic tree was constructed using the neighbor-joining method based on Tamura-Nei model. The data set was resampled 1,000 times to generate bootstrap values [23]. The sequences obtained from this study were deposited in GenBank under accession numbers (OL677550-OL677566).

SFTSV was detected in male, female, and nymphal ticks of $H$. longicornis and H. flava, but not in I. nipponensis and I. ovatus (Table 1). Infection rate (IR) in H. longicornis was 5.9\% (1.9\% in males, $6.4 \%$ in females, and $6.0 \%$ in nymphs) and that in H. flava was $7.7 \%$ (8.7\% in males, $8.3 \%$ in females, and 7.6\% in nymphs) (Table 1). Based on developmental stages, IR was 


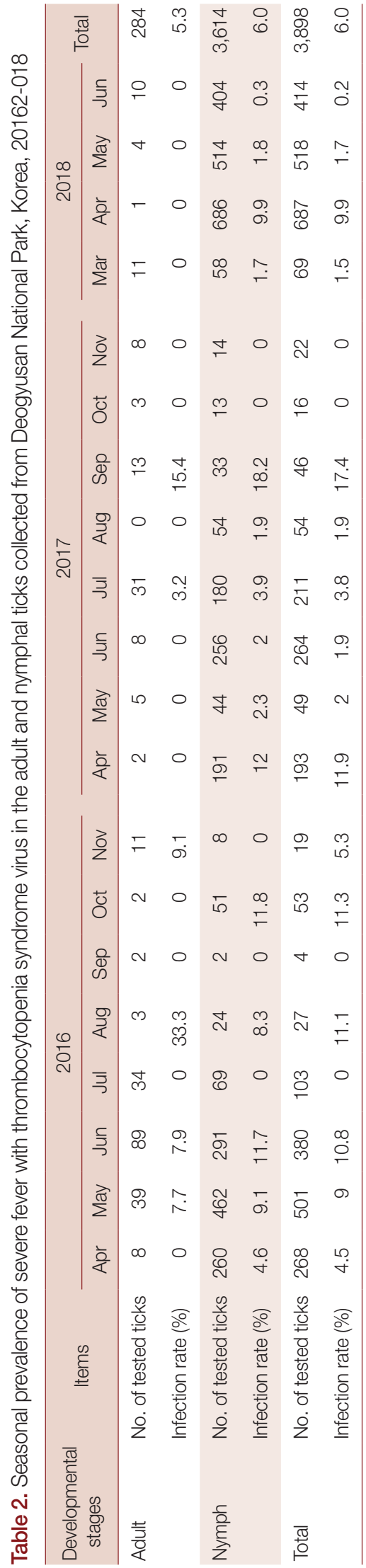

observed to be $5.3 \%$ in the adults and $6.0 \%$ in the nymphs. Minimum field infection rate (MFIR; number of positive pools/ number of tested ticks $\times 100$ ) was $2.47 \%$ in the larvae. The year-wise IR was $8.0 \%(108 / 1,355)$ in 2016, 5.4\% (46/855) in 2017, and 4.7\% (79/1,688) in 2018. In spring (April-June), IR was slightly higher than the annual average every year $(8.5 \%$ in 2016, 5.7\% in 2017, and $4.8 \%$ in 2018).

Of the 233 SFTSV-positive ticks, 109 DNA samples were selected and sequenced from each developmental stage, collection date, and species. The sequences (346 bp long) were very similar to that of the $S$ segment of SFTSV RNA and were subgrouped into 17 haplotypes. Phylogenetic analysis revealed that all obtained haplotypes were clustered into 2 clades: B-2 and B-3 (Fig. 1B).

Of the 109 sequences obtained, 101 (92.7\%) were clustered in clade B-2 and 8 (7.3\%) were grouped in B-3 (Fig. 1B). However, no sequences were included in other clades such as $A$, B-1, D, and F. The major haplotype (DY173) comprised 68 sequences $(62.4 \%)$ and was closely related to the Korean isolate Dog22, with $99.1 \%$ identity.

Our 3-year field surveillance indicates that $H$. longicornis is a dominant tick species in the surveyed area of Deogyusan National Park. The species has also been previously reported as dominant in Ganghwa-do, Gyeonggi-do, Daejeon, Gyeongbuk, and 5 national parks $[16-18,21,24]$. Moreover, H. longicornis was observed to be the overwhelmingly dominant species in every season, month, and year in this study. This may be associated with the choice of grasslands as the sampling habitat. H. longicornis has a 3-host life cycle and 3 distinct developmental stages in one year [25]. Regarding the seasonal distribution of the H. longicornis developmental stages, the sequential dynamic changes in tick population peaks (adults, nymphs, and larvae) were observed in Korea by several studies, including the present study, and also in China $[17,21,25]$. The number of adults and nymphs decreased in July and larval population surged in August, indicating that oviposition period of H. longicornis might be pre-summer and could affect the second peak of nymphs observed in autumn [21,25]. Adults or nymphs perhaps hibernate under leaves or underground in the winter [26]. It was previously reported that nymphs and adults of $H$. longicornis could survive during winter and that nymph population was highest in spring in Korea [21,27].

Epidemiological studies about the prevalence of SFTSV in ticks have generally been conducted based on pooling method for reasons of convenience, economic benefit, and high sam- 
ple size of ticks. In Korea, studies on SFTSV prevalence in pooled ticks from vegetation have reported an MFIR of 0-0.6\% ( $0.5 \%$ in 8 provinces, $0.6 \%$ in Gyeongbuk province, and $0 \%$ in Ganghwa-do and Gyeonggi provinces) $[17,18,28,29]$. On the other hand, when analyses were made without using the pooling method, higher SFTSV prevalence in ticks was observed, with an IR of 3.6\% [16]. In this study, an IR of 5.98\% was observed, which is much higher than those reported in previous studies. These observations suggest that MFIR can not represent real IR in tick population and basing the sampling process on individual tick assay may be more suitable for the epidemiological studies on the prevalence of pathogens in ticks.

Although we only had data of one year (2017) on larval MFIR, the observed value of $2.5 \%$ was markedly higher than $0.3 \%$, as reported in a previous study [16]. Recently, it has been reported that SFTSV was detected at all developmental stages including adults, nymphs, larvae, and eggs of $H$. longicornis ticks in Korea and China [16,29,30]. Moreover, the presence of SFTSV was also confirmed in several organs of $H$. longicornis larvae, nymphs, and adults [15]. These studies, including the present study, suggest that SFTSV could circulate in the wild by transovarial and transstadial transmissions.

Based on phylogenetic analysis, several previous studies have clustered the SFTSV strains, which can be broadly divided into 2 groups: the Chinese and the Korean/Japanese clades. In this study, phylogenetic analysis of SFTSV strains was performed and sequences were clustered as suggested by Yun et al. [31]. Clades A, D, and F included the Chinese strains while clade B consisted of the Korean/Japanese strains. Our results, based on partial sequences of SFTSV S segment, show that $92.7 \%$ of sequences were clustered in clade B-2 and 7.3\% sequences were included in B-3 (Fig. 1B). Many Korean and Japanese isolates were mixed and included in clade B-2 clade but it included no Chinese strains [31]. In contrast, in clade B-3, many Chinese and Korean isolates were clustered with few Japanese strain. These observations indicate that the Korean SFTSV strains are more closely related to the Japanese than the Chinese strains (Fig. 1B). However, this study has some limitation such as using only partial S segment sequences of SFTSV, local collection site, etc. Therefore, for better understanding of the Korean SFTSV characteristics, continuous massive surveillance and evolutionary study for SFTSV are necessary.

To the best of our knowledge, this study has reported the highest IR of SFTSV till date. Annual SFTS cases show no de- clining trend and several patients with SFTS have succumbed to the disease in Korea. SFTSV-specific vaccines or drugs are not yet developed. It is, therefore, suggested that monitoring the spread of infection among the arthropod vectors, wild/domesticated/companion animals, and humans should be extended and intensified to minimize potential risks associated with SFTSV transmission in Korea.

\section{ACKNOWLEDGMENTS}

This work was supported by a grant of the National Institute of Environmental Research (NIER-2017-353), Korea.

\section{CONFLICT OF INTEREST}

The authors declare that they have no conflicts of interest in the publication of this paper.

\section{REFERENCES}

1. Walker PJ, Siddell SG, Lefkowitz EJ, Mushegian AR, Adriaenssens EM, Alfenas-Zerbini P, Davison AJ, Dempsey DM, Dutilh BE, García ML, Harrach B, Harrison RL, Hendrickson RC, Junglen S, Knowles NJ, Krupovic M, Kuhn JH, Lambert AJ, Lobocka M, Nibert ML, Oksanen HM, Orton RJ, Robertson DL, Rubino L, Sabanadzovic S, Simmonds P, Smith DB, Suzuki N, Van Dooerslaer K, Vandamme AM, Varsani A, Zerbini FM. Changes to virus taxonomy and to the International Code of Virus Classification and Nomenclature ratified by the International Committee on Taxonomy of Viruses (2021). Arch Virol 2021; 166: 2633-2648. https://doi.org/10.1007/s00705-021-05156-1

2. Yu XJ, Liang MF, Zhang SY, Liu Y, Li JD, Sun YL, Zhang L, Zhang QF, Popov VL, Li C, Qu J, Li Q, Zhang YP, Hai R, Wu W, Wang Q, Zhan FX, Wang XJ, Kan B, Wang SW, Wan KL, Jing HQ, Lu JX, Yin WW, Zhou H, Guan XH, Liu JF, Bi ZQ, Liu GH, Ren J, Wang H, Zhao Z, Song JD, He JR, Wan T, Zhang JS, Fu XP, Sun LN, Dong XP, Feng ZJ, Yang WZ, Hong T, Zhang Y, Walker DH, Wang Y, Li DX. Fever with thrombocytopenia associated with a novel bunyavirus in China. N Engl J Med 2011; 364: 1523-1532. https://doi.org/10.1056/NEJMoa1010095

3. Kim KH, Yi J, Kim G, Choi SJ, Jun KI, Kim NH, Choe PG, Kim NJ, Lee JK, Oh MD. Severe fever with thrombocytopenia syndrome, South Korea, 2012. Emerg Infect Dis 2013; 19: 18921894. https://doi.org/10.3201/eid1911.130792

4. Takahashi T, Maeda K, Suzuki T, Ishido A, Shigeoka T, Tominaga T, Kamei T, Honda M, Ninomiya D, Sakai T, Senba T, Kaneyuki S, Sakaguchi S, Satoh A, Hosokawa T, Kawabe Y, Kurihara S, Izumikawa K, Kohno S, Azuma T, Suemori K, Yasukawa M, Mizutani T, Omatsu T, Katayama Y, Miyahara M, Ijuin M, Doi K, Okuda 
M, Umeki K, Saito T, Fukushima K, Nakajima K, Yoshikawa T, Tani H, Fukushi S, Fukuma A, Ogata M, Shimojima M, Nakajima N, Nagata N, Katano H, Fukumoto H, Sato Y, Hasegawa H, Yamagishi T, Oishi K, Kurane I, Morikawa S, Saijo M. The first identification and retrospective study of severe fever with thrombocytopenia syndrome in Japan. J Infect Dis 2014; 209: 816-827. https://doi.org/10.1093/infdis/jit603

5. Matsuno K, Nonoue N, Noda A, Kasajima N, Noguchi K, Takano A, Shimoda H, Orba Y, Muramatsu M, Sakoda Y, Takada A, Minami S, Une Y, Morikawa S, Maeda K. Fatal tickborne phlebovirus infection in captive cheetahs, Japan. Emerg Infect Dis 2018; 24: 1726-1729. https://doi.org/10.3201/eid2409.171667

6. Matsuu A, Momoi Y, Nishiguchi A, Noguchi K, Yabuki M, Hamakubo E, Take M, Maeda K. Natural severe fever with thrombocytopenia syndrome virus infection in domestic cats in Japan. Vet Microbiol 2019; 236: 108346. https://doi.org/10.1016/j.vetmic. 2019.06.019

7. Han SW, Kang JG, Byeon AR, Cho YK, Choi KS, Chae JS. Severe fever with thrombocytopenia syndrome in canines from the Republic of Korea. Ticks Tick Borne Dis 2020; 11: 101454. https:// doi.org/10.1016/j.ttbdis.2020.101454

8. Nam SJ, Oh YI, Kim HJ, Cheon DS, Noh SJ, Hong YJ. Unusual case of severe fever with thrombocytopenia syndrome showing clinical manifestations in a companion dog. Vet Med Sci 2020; 6: 353-358. https://doi.org/10.1002/vms3.261

9. Peng SH, Yang SL, Tang SE, Wang TC, Hsu TC, Su CL, Chen MY, Shimojima M, Yoshikawa T, Shu PY. Human case of severe fever with thrombocytopenia syndrome virus infection, Taiwan, 2019. Emerg Infect Dis 2020; 26: 1612-1614. https://doi.org/10.3201/ eid2607.200104

10. Tran XC, Yun Y, Le Van An SH, Thao NT, Man PK, Yoo JR, Heo ST, Cho NH, Lee KH. Endemic severe fever with thrombocytopenia syndrome, Vietnam. Emerg Infect Dis 2019; 25: 10291031. https://doi.org/10.3201/eid2505.181463

11. Daengnoi C, Ongkittikul S, Watanawong R, Rompho P. Severe fever with thrombocytopenia syndrome virus: the first case report in Thailand. Bangk Med J 2020; 16: 204. https://doi.org/ 10.31524/bkkmedj.2020.22.001

12. Lin TL, Ou SC, Maeda K, Shimoda H, Chan JP, Tu WC, Hsu WL, Chou CC. The first discovery of severe fever with thrombocytopenia syndrome virus in Taiwan. Emerg Microbes Infect 2020; 9: 148-151. https://doi.org/10.1080/22221751.2019.1710436

13. Win AM, Nguyen YTH, Kim Y, Ha NY, Kang JG, Kim H, San B, Kyaw O, Htike WW, Choi DO, Lee KH, Cho NH. Genotypic heterogeneity of Orientia tsutsugamushi in scrub typhus patients and thrombocytopenia syndrome co-infection, Myanmar. Emerg Infect Dis 2020; 26: 1878-1881. https://doi.org/10.3201/eid2608.200135

14. Zohaib A, Zhang J, Saqib M, Athar MA, Hussain MH, Chen J, Sial AU, Tayyab MH, Batool M, Khan S, Luo Y, Waruhiu C, Taj Z, Hayder Z, Ahmed R, Siddique AB, Yang X, Qureshi MA, Ujjan IU, Lail A, Khan I; Sajjad-Ur-Rahman, Zhang T, Deng F, Shi Z, Shen S Serologic evidence of severe fever with thrombocytopenia syndrome virus and related viruses in Pakistan. Emerg Infect Dis
2020; 26: 1513-1516. https://doi.org/10.3201/eid2607.190611

15. Zhuang L, Sun Y, Cui XM, Tang F, Hu JG, Wang LY, Cui N, Yang ZD, Huang DD, Zhang XA, Liu W, Cao WC. Transmission of severe fever with thrombocytopenia syndrome virus by Haemaphysalis longicornis ticks, China. Emerg Infect Dis 2018; 24: 868-871. https://doi.org/10.3201/eid2405.151435

16. Jo YS, Kang JG, Chae JB, Cho YK, Shin JH, Jheong WH, Chae JS. Prevalence of severe fever with thrombocytopenia syndrome virus in ticks collected from national parks in Korea. Vector Borne Zoonotic Dis 2019; 19: 284-289. https://doi.org/10.1089/vbz. 2018.2338

17. Kim-Jeon MD, Jegal S, Jun H, Jung H, Park SH, Ahn SK, Lee J, Gong YW, Joo K, Kwon MJ, Roh JY, Lee WG, Bahk YY, Kim TS. Four year surveillance of the vector hard ticks for SFTS, Ganghwa-do, Republic of Korea. Korean J Parasitol 2019; 57: 691-698. https://doi.org/10.3347/kjp.2019.57.6.691

18. Jung M, Kho JW, Lee WG, Roh JY, Lee DH. Seasonal occurrence of Haemaphysalis longicornis (Acari: Ixodidae) and Haemaphysalis flava, vectors of severe fever with thrombocytopenia syndrome (SFTS) in South Korea. J Med Entomol 2019; 56: 1139-1144. https://doi.org/10.1093/jme/tjz033

19. Luo LM, Zhao L, Wen HL, Zhang ZT, Liu JW, Fang LZ, Xue ZF, Ma DQ, Zhang XS, Ding SJ, Lei XY, Yu XJ. Haemaphysalis longicornis ticks as reservoir and vector of severe fever with thrombocytopenia syndrome virus in China. Emerg Infect Dis 2015; 21: 1770-1776. https://doi.org/10.3201/eid2110.150126

20. Yamaguti N, Tipton VJ, Keegan HL, Toshioka S. Ticks of Japan, Korea, and the Ryukyu islands. Brigham Young Univ Sci Bull Biol Ser 1971; 15: 1-226. https://scholarsarchive.byu.edu/byuscib/vol15/iss1/1

21. Lee SY, Kang JG, Jeong HS, Kim WM, Son KD, Kim JS, Oh SS, Cho YK, Jheong WH, Chae JS. Complete genome sequences of two severe fever with thrombocytopenia syndrome virus strains isolated from a human and a dog in the Republic of Korea. Microbiol Resour Announc 2019; 8: e01695-18. https://doi.org/10.1128/ MRA.01695-18

22. Larkin MA, Blackshields G, Brown NP, Chenna R, McGettigan PA, McWilliam H, Valentin F, Wallace IM, Wilm A, Lopez R, Thompson JD, Gibson TJ, Higgins DG. Clustal W and Clustal X version 2.0. Bioinformatics 2007; 23: 2947-2948. https://doi. org/10.1093/bioinformatics/btm404

23. Kumar S, Stecher G, Tamura K. MEGA7: molecular evolutionary genetics analysis version 7.0 for bigger datasets. Mol Biol Evol 2016; 33: 1870-1874. https://doi.org/10.1093/molbev/msw054

24. Seo JW, Han SY, Sung SH, Jung EY, Kim JH, Lee SJ, Yoo SS. Survey on tick distribution and tick-borne pathogens in Daejeon and adjacent areas in South Korea. Ticks Tick Borne Dis 2021; 12: 101711. https://doi.org/10.1016/j.ttbdis.2021.101711

25. Zheng H, Yu Z, Zhou L, Yang X, Liu J. Seasonal abundance and activity of the hard tick Haemaphysalis longicornis (Acari: Ixodidae) in North China. Exp Appl Acarol 2012; 56: 133-141. https://doi. org/10.1007/s10493-011-9505-x

26. Gray JS, Kahl O, Lane RS, Levin ML, Tsao JI. Diapause in ticks of 
the medically important Ixodes ricinus species complex. Ticks Tick Borne Dis 2016; 7: 992-1003. https://doi.org/10.1016/j.ttbdis.2016.05.006

27. Kim JY, Jung M, Kho JW, Song H, Moon K, Kim YH, Lee DH. Characterization of overwintering sites of Haemaphysalis longicornis (Acari: Ixodidae) and tick infection rate with severe fever with thrombocytopenia syndrome virus from eight provinces in South Korea. Ticks Tick Borne Dis 2020; 11: 101490. https://doi. org/10.1016/j.ttbdis.2020.101490

28. Park SW, Song BG, Shin EH, Yun SM, Han MG, Park MY, Park C, Ryou J. Prevalence of severe fever with thrombocytopenia syndrome virus in Haemaphysalis longicornis ticks in South Korea. Ticks Tick Borne Dis 2014; 5: 975-977. https://doi.org/10.1016/ j.ttbdis.2014.07.020
29. Lee J, Moon K, Kim M, Lee WG, Lee HI, Park JK, Kim YH. Seasonal distribution of Haemaphysalis longicornis (Acari: Ixodidae) and detection of SFTS virus in Gyeongbuk Province, Republic of Korea, 2018. Acta Trop 2021; 221: 106012. https://doi.org/10.1016/ j.actatropica.2021.106012

30. Wang S, Li J, Niu G, Wang X, Ding S, Jiang X, Li C, Zhang Q, Liang $\mathrm{M}, \mathrm{Bi} \mathrm{Z}, \mathrm{Li} \mathrm{D}$. SFTS virus in ticks in an endemic area of China. Am J Trop Med Hyg 2015; 92: 684-689. https://doi.org/10.4269/ajtmh.14-0008

31. Yun SM, Park SJ, Kim YI, Park SW, Yu MA, Kwon HI, Kim EH, Yu KM, Jeong HW, Ryou J, Lee WJ, Jee Y, Lee JY, Choi YK. Genetic and pathogenic diversity of severe fever with thrombocytopenia syndrome virus (SFTSV) in South Korea. JCI Insight 2020; 5: e129531. https://doi.org/10.1172/jci.insight.129531 
